\title{
MANAJEMEN KESISWAAN PADA SEKOLAH DASAR
}

\section{STUDENTS' MANAGEMENT AT ELEMENTARY SCHOOL}

\author{
RR Aliyyah'1a, Widyasari' ${ }^{1}$ D Mulyadi², S Ikhwan ${ }^{3}$, dan AG Prananosa4 \\ 1 Program Studi Pendidikan Guru Sekolah Dasar, FKIP Universitas Djuanda, Bogor, Indonesia \\ ${ }_{2}^{2}$ Program Studi Akuntasi, Sekolah Tinggi Ilmu Ekonomi Pertiwi, Bekasi, Indonesia \\ ${ }^{3}$ Program Studi Pendidikan Bahasa Arab, Sekolah Tinggi Agama Islam Nurul Iman, Bogor, Indonesia \\ ${ }^{4}$ Program Studi Pendidikan Bahasa dan Sastra Indonesia, Sekolah Tinggi Keguruan dan Ilmu \\ Pendidikan PGRI Lubuklinggau, Bengkulu. Indonesia \\ a Korespondensi: Rusi Rusmiati Aliyyah, Email: rusi.rusmiati@unida.ac.id \\ (Diterima: 16-02-2019; Ditelaah: 17-02-2019; Disetujui: 24-03-2019)
}

\begin{abstract}
This research aims to get the pattern of student management in Elementary Schools (SD) according to the Graduates Competency Standards (SKL). The study was conducted at Pertiwi Elementary School in Bogor city using qualitative methods with the type of case study research. Data collection techniques are carried out through interviews, observation, and documentation. Data analysis uses the Miles and Huberman Model which consist of data collection, data reduction, data presentation and verification or conclusion. Examination of the validity of the data using triangulation. The results showed: (1) Management of students was carried out starting from planning, student admission, student orientation, grouping / placement of students, reporting of evaluation results, level and non-level systems, mutations and drop out of students, special services for students, disciplinary coaching of students, student organizations, and graduations and alumni. (2) Teachers become pioneers in the management of students because they have an agent role in the progress of students' development.
\end{abstract}

Keywords: case studies, management of students, primary schools.

\begin{abstract}
ABSTRAK
Penelitian ini bertujuan untuk mendapatkan pola manajemen kesiswaan. Penelitian ini dilakukan pada SD Pertiwi kota Bogor menggunakan metode kualitatif dengan jenis penelitian studi kasus. Teknik pengumpulan data dilakukan melalui wawancara, observasi, dan dokumentasi. Analisis data menggunakan Model Miles dan Huberman yang terdiri dari pengumpulan data, reduksi data, penyajian data, dan verifikasi atau pengambilan kesimpulan. Pemeriksaan keabsahan data menggunakan triangulasi. Hasil penelitian menunjukan: (1) Pengelolaan peserta didik dilakukan mulai dari perencanaan, penerimaan peserta didik, orientasi peserta didik, pengelompokkan/penempatan peserta didik, pelaporan hasil evaluasi, sistem tingkat dan nontingkat, mutasi dan dropout peserta didik, layanan peserta didik, pembinaan disiplin peserta didik, organisasi peserta didik, serta kelulusan dan alumni; (2) Guru menjadi pionir dalam manajemen kesiswaan karena memiliki peran sebagai agen dalam kemajuan perkembangan peserta didik.
\end{abstract}

Kata kunci: pengelolaan peserta didik, sekolah dasar, studi kasus. 
Aliyyah, R. R., Widyasari, Mulyadi, D., Ikhwan, S., \& Prananosa, A. G. (2018). Manajemen Kesiswaan pada Sekolah Dasar. Didaktika Tauhidi: Jurnal Pendidikan Guru Sekolah Dasar, 6(1): 29-40.

\section{PENDAHULUAN}

Peserta didik merupakan sentral layanan sekolah yang memiliki cakupan yang sangat luas, yakni membantu proses siswa pada tahap pertumbuhan dan perkembangan diri melalui pembelajaran di sekolah. Pengelolaan peserta didik bertujuan mengelola segala aktivitas dalam bidang kesiswaan agar kegiatan pembelajaran berjalan dengan baik (Gunawan \& Djum Djum, 2017). Manajemen kesiswaan adalah usaha pengaturan atau kegiatan pencatatan siswa mulai dari masuk sampai dengan lulus sekolah (Prihatin, 2011). Manajemen kesiswaan adalah kegiatan pengurusan segala hal yang berkaitan dengan siswa mulai dari penerimaan hingga keluarnya peserta didik dari suatu sekolah. Pengelolaan peserta didik sangat penting dalam dunia pendidikan, karena tanpa pengelolaan peserta didik, sekolah tidak dapat mengetahui cara mengatur kegiatan dalam sekolah dan mendapatkan tujuan yang diinginkan. Terdapat berbagai aktivitas yang saling berhubungan, baik dari fungsionalitasnya maupun tujuan yang ditargetkan. Melalui pengelolaan yang benar, akan tercapai prestasi belajar yang baik. Implementasi manajemen kesiswaaan di sekolah akan mampu memberikan keluaran atau alumni yang kompeten, sehingga dapat berpengaruh terhadap lingkungan dan kemajuan intelektual. Selain itu, sekolah memiliki mutu yang baik sebagai sasaran sarana pendidikan masyarakat. Melalui kegiatan pengaturan siswa yang baik, maka pasti menghasilkan lulusan yang handal. Pengelolaan peserta didik dimulai dari proses rekrutmen, seleksi, orientasi, penempatan siswa, layanan kesiswaan, pembinaan kesiswaan, sampai pada manajemen alumni pada SD. Karena siswa merupakan instrumen ujung tombak dari sebuah institusi pendidikan, maka input, proses, out put dan out come nya menjadi indikator yang harus senantiasa dikelola.

SD Pertiwi merupakan sekolah yang berada di Kotamadya Bogor dengan perolehan prestasi dari berbagai dimensi peserta didiknya, mulai dari akademik, dan non akademik. Berbagai prestasi tersebut diraih melalui proses pembinaan yang kontinu dilakukan sekolah untuk siswa. Proses pengelolaan kesiswaan tersebut terlihat mulai dari berbagai syarat dalam rekrutmen siswa baru. Setelah siswa dinyatakan diterima, maka langkah selanjutnya SD tersebut selalu memberikan treatment kepada siswa sehingga siswa tersebut menjadi alumni dengan berbagai potensi yang telah dikembangkan. Proses pembinaan siswa tersebut menjadi bagian yang unik karena siswa diberikan pembelajaran yang kontinu tentang kegiatan akademik dan non akademik berbasis keunggulan lokal sekolah, untuk kemudian dapat menjadikan siswa terampil dan pandai beradaptasi dengan kehidupan nyata.

\section{Pengertian Manajemen Kesiswaan}

Pengelolaan peserta didik atau dengan kata lain manajemen kesiswaan adalah teknik mengatur seluruh siswa mulai dari masuk sekolah sampai dengan mereka lulus sekolah (Imron \& Burhanudin, 2003). Manajemen kesiswaan merujuk pada aktivitas atau kegiatan pencatatan siswa 
sejak dari awal diterima, kemudian diberikan pembinaan dan berakhir pada terselesaikannya proses pembelajaran serta menjadi alumni setelah selesai melaksanakan pembelajaran (Prihatin, 2011). Dengan demikian, manajemen kesiswaan adalah suatu cara pengaturan peserta didik, mulai dari input, proses, output, dan menjadi outcome dari satuan pendidikan.

Adapun tujuan dan fungsi manajemen kesiswaan adalah: (1) meningkatkan pengetahuan, keterampilan, dan psikomotorik siswa; (2) mendidik dan membina kemampuan, bakat, dan minat; dan (3) mencapai kebahagiaan kesejahteraan hidup, belajar dengan baik, dan tercapai cita-citanya (Imron, 2011). Tujuan pengelolaan kesiswaan yakni mengelola aktivitas kesiswaan untuk membantu kegiatan belajar sehingga sesuai, disiplin dan sesuai prosedur, serta dapat memberi masukan dalam mencapai sasaran yang sudah disepakati (Kristiawan, 2017). Fungsi umum pengelolaan kesiswaan yakni sarana bagi siswa untuk mengembangkan diri secara individualitas, sosial, kebutuhan, maupun potensi-potensi peserta didik (Imron \& Burhanudin, 2003).

Fungsi pengelolaan kesiswaan secara khusus, yaitu: (1) pengembangan individualitas, yakni agar siswa mampu mengembangkan potensi individualitasnya; (2) pengembangan sosial siswa, yakni supaya siswa mampu melakukan sosialisasi dengan masyarakatnya; (3) penyaluran aspirasi dan harapan siswa, yakni supaya terefleksikan kesenangan, dan minat siswa; dan (4) pemenuhan dan kesejahteraan siswa, yakni supaya siswa tentram dalam menjalankan pendidikannya. Fungsi pengelolaan kesiswaan yakni untuk sarana mengembangkan diri (Kristiawan, 2017).

\section{Prinsip Pengelolaan Kesiswaan}

Prinsip adalah asas atau pondasi pokok fakta untuk pola berfikir dan bertindak. Prinsip pengelolaan kesiswaan yakni: (1) untuk mengatur seluruh pengelolaan sekolah; (2) memberikan misi pendidikan; (3) kegiatan pengelolaan kesiswaan berupaya menyatukan siswa dengan keadaan keluarga yang beragam dan banyak perbedaanya; (4) sebagai upaya pengaturan terhadap pebimbing peserta didik; dan (5) kegiatan manajemen peserta didik, senantiasa berlatar sesuai dengan fungsinya (Imron \& Burhanudin, 2003). Sehingga, prinsip pengelolaan kesiswaan adalah mengutamakan peserta didik untuk kegiatan utama dalam kemajuan lembaga pendidikan. Ruang Lingkup Pengelolaan Kesiswaan yakni pengaturan siswa sejak ditetapkan sebagai siswa yang diterima di satuan pendidikan sampai pada siswa tersebut dinyatakan sebagai alumni.

\section{Ruang Lingkup Pengelolaan Kesiswaan}

Pengelolaan kesiswaan adalah:

perencanaan kesiswaan; (2) rekrutmen siswa atau biasa disebut dengan PPDB dengan kegiatan kebijakan penerimaan peserta didik; (3) orientasi siswa atau biasa disebut dengan Masa Orientasi Peserta Didik (MOPD); (4) pengelompokan atau penempatan siswa dengan tujuan memudahkan pemberian layanan selama menjadi siswa di satuan pendidikan; (5) pencatatan absensi dengan tujuan memberikan pembinaan kedisiplinan; (6) evaluasi kesiswaan dengan melakukan kegiatan pengukuran perkembangan dan prestasi peserta didik; (7) pelaporan hasil evaluasi dengan tujuan untuk memberikan timbal balik akuntabilitas atau report kegiatan siswa selama di sekolah atas 
kepercayaan orang tua kepada lembaga; (8) mutasi dan dropout peserta didik yakni proses perpindahan peserta didik; (9) layanan khusus penunjang agar siswa lancar dan mampu mengembangkan diri; (10) pembinaan disiplin dengan tahapan perencanaan meliputi membuat aturan dan menentukan konsekuensi; (11) organisasi peserta didik di sekolah yang terdiri dari kegiatan intrakurikuler dan ekstrakurikuler; dan (12) kegiatan akhir sampai pada perpisahan dan lulusnya siswa yang bertujuan menilai pencapaian SKL untuk semua mata pelajaran sesuai programnya sebagai bentuk transparasi, profesional, dan akuntabel lembaga (Kudianta, 2016). Guru berperan sebagai inspirator, informator, dan demonstrator (Djamarah, 2010).

\section{METODE}

Metode penelitian menggunakan studi kasus, yakni proses pengumpuan data melalui teknik dan sumber informasi yang efektif (Yusuf, 2015). Jenis penelitian ini menggunakan pendekatan kualitatif dengan tujuan untuk mendeskripsikan dan memperoleh secara jelas gambaran tentang pengelolaan peserta didik. Sumber data didapat dari guru, kepala sekolah, siswa dan orangtua. Penelitian ini menggunakan triangulasi observasi, wawancara, serta studi dokumentasi (Sugiyono, 2017). Analisis data menggunakan reduksi, penyajian data, dan verifikasi atau penarikan kesimpulan (Yusuf, 2015).

\section{HASIL DAN PEMBAHASAN}

\section{Hasil}

\section{Perencanaan Peserta Didik}

Aktivitas pertama perencanaan adalah melakukan: (1) perkiraan, yakni melakukan sensus di lingkungan sekitar satuan pendidikan dan menentukan jumlah siswa yang diterima serta guru yang terdapat di sekolah; (2) perumusan, yaitu menentukan visi dan misi sekolah; (3) kebijakan; (4) pemograman dengan kategori program mandiri, bermutu, berbudaya, dan religius; (5) langkah-langkah, yaitu melakukan segala sesuatu, mulai dari sensus hingga kelulusan menjadi alumni; (6) penjadwalan; dan (7) pembiayaan, dengan biaya masuk awal sebesar Rp 10.000.000,- yang meliputi seluruh pembiayaan, tidak termasuk biaya bulanan siswa. SD Pertiwi melakukan sensus sekolah guna mengetahui informasi para calon peserta didik di masyarakat, sensus yang dilakukan dimulai dari masyarakat sekitar yang dekat dengan sekolah, latar belakang masyarakat, dan mengetahui usia umum.

\section{Penerimaan Peserta Didik}

Para calon siswa yang diterima maksimal adalah 160 peserta didik, dibagi menjadi 5 kelas (32 peserta didik per kelas) dalam setiap angkatannya. Prosedur PPDB terdiri dari pembentukan panitia, sosialisasi, pelaksanaan, seleksi, pengumuman siswa yang diterima, observasi bakat siswa. PPDB dilaksanakan kontinu setiap tahun pada bulan April. Sebelum PPDB pantia mensosialisasikan kepada masyarakat dan membagikan brosur ke TK (Taman KanakKanak) berupa promosi dan syarat ketentuan para calon siswa. Tahap berikutnya adalah observasi untuk melihat 
kemampuan siswa, lalu 3 hari kemudian dilakukan pengumuman hasil seleksi.

\section{Orientasi Peserta Didik}

Setelah calon diterima, pihak sekolah mengadakan perkenalan lingkungan sekolah atau kegiatan orientasi. Kegiatan orientasi dimulai dari perkenalan guru, perkenalan program sekolah, perkenalan lingkungan, dan memotivasi siswa dengan cara menampilkan siswa-siswa berprestasi.

\section{Pengelompokkan Siswa}

Pengelompokkan atau penempatan peserta didik tidak dipisahkan. Setiap satu kelas, terdapat peserta didik dengan kemampuan berbeda-beda, terdapat laki-laki dan perempuan, latar belakang ekonomi, tempat tinggal, bahkan siswa berkebutuhan khusus dapat berbaur dengan siswa lainnya. Pada jam pelajaran tambahan bagi kelas 6, peserta didik dikelompokan sesuai dengan kemampuan, keadaan tersebut dibuat dengan tujuan agar dapat meningkatkan motivasi berprestasi siswa dan menimbulkan daya saing setiap peserta didik.

\section{Pencatatan Presensi Siswa}

Pencatatan kehadiran dan ketidakhadiran peserta didik menggunakan daftar harian dan daftar absen. Siswa datang dan melihat nama mereka pada daftar buku daftar harian siswa setiap kelas, siswa berlombalomba memparafkan (tanda tangan) untuk kelas atas. Setiap bulan, guru kelas memperlihatkan persentase kehadiran setiap anak. Jika terdapat yang tidak masuk sampai dengan 3 hari atau lebih, maka guru harus melaksanakan home visit.

\section{Evaluasi Peserta Didik}

Evaluasi dilakukan dengan berkala, yaitu evaluasi harian, mingguan, bulanan, tengah semester, akhir semester, hingga Ujian Nasional Berbasis Komputer (UNBK) yang diadakan serentak di seluruh Indonesia. Hal tersebut, guna menyukseskan prestasi melatih pemahaman dan mengukur kompetensi akademik siswa melalui ujian tertulis. Teknik evaluasi yang digunakan guru dengan tes atau non tes. Tes diberikan dalam soal latihan setiap selesai tema pembelajaran, sedangkan evaluasi non tes diberikan dalam bantuk tes lisan (tanyajawab) dan perilaku. Contohnya, teknik evaluasi untuk peserta didik pada tingkat 1 , tidak bisa dilaksanakan melalui teknik tes tertulis, maka guru memberikan tes lisan. Setiap minggu, seluruh guru selalu mengadakan penilai harian untuk semua tema. Selain itu, juga mengadakan penilaian sikap setiap hari. Penilaian sikap menjadi fokus pada SD yang akan dicatat oleh guru pada jurnal. Misalnya jika siswa tiba lebih dulu ke sekolah guru mencatat di di jurnal bahwa anak ini rajin berangkat pagi dan menjadi tauladan bagi siswa lain, selain itu terdapat siswa dengan sikap terpuji, sampai menyimpang.

\section{Pelaporan Hasil Evaluasi Peserta Didik}

Setiap semester guru selalu memasukan hasil rekap nilai para siswa ke dalam raporan penilaian peserta didik. Pelaporan hasil evaluasi selalu dilakukan pada tengah semester (di bulan Maret) dan akhir semester (di bulan Mei).

\section{Sistem Tingkat dan Nontingkat Peserta Didik}

Sistem tingkat dan non tingkat peserta didik atau biasa disebut dengan istilah kenaikan 
kelas. Tidak terdapat siswa dengan keadaan dan status tertinggal maupun naik terlebih dahulu atau bisa disebut dengan istilah akselerasi kenaikan kelas. Sistem tingkat selalu memperhatikan perkembangan kecakapan kognitif, afektif, juga psikomotorik. Pola non tingkat siswa di SD Pertiwi belum pernah dilaksanakan, karena kemampuan siswa selalu sama pada setiap angkatan peserta didik.

\section{Mutasi dan Dropout Peserta Didik}

Terdapat mutasi siswa karena masalah orang tua pindah tugas misalnya dari dalam kota ke luar kota atau sebaliknya, dan penyebab lain siswa mutasi karena pindah rumah, dan masalah rumah tangga. Kebijakan mutasi siswa dari luar ke dalam selalu melihat kondisi, jika jumlah siswa sudah banyak maka tidak diterima karena beberapa alasan. Terdapat syarat mutasi untuk masuk ke SD Pertiwi, diantaranya: (1) surat pindah resmi dari sekolah sebelumnya; (2) tempat tinggal; dan (3) evaluasi kemampuan akademik. Tidak ada dropout peserta didik, ketika ada masalah, pihak sekolah akan membantu dengan mendata identitas peserta didik. Jika terdapat peserta didik yang mengalami permasalahan ekonomi, pihak sekolah memberikan keringanan untuk tetap belajar, dan sekolah akan bersubsidi dengan beasiswa. Sekolah tidak ingin anak didiknya dropout karena masalah ekonomi. Sekolah ini pun sangat memelihara silaturahmi dan ukhuwah antar orangtua peserta didik.

\section{Pelayanan Khusus Peserta Didik}

Layanan khusus untuk menunjang kebutuhan peserta didik yaitu UKS (Usaha Kesehatan Sekolah), kantin, perpustakaan, kamar mandi, tempat mencuci tangan, multimedia, dan sarana prasana lainnya yang menunjang kebutuhan peserta didik.
Layanan khusus yang disediakan terdiri dari kantin, UKS, Toilet, perpustakaan, dan tempat mencuci tangan.

\section{Pembinaan Disiplin Peserta Didik}

Pembinaan disiplin dilakukan setiap hari. Ketika terdapat anak yang melanggar dicatat dan bagi anak yang sudah disiplin mengikuti peraturan sekolah akan diapresiasi. Bagi anak yang melanggar diingatkan untuk menerapkan disiplin. Setiap hari anak akan berbaris untuk catatan jurnal (untuk mencatat sikap sosial dan sikap spiritual). Di kelas guru melakukan pembinaan disiplin dengan catatan jurnal, bagi anak-anak yang sangat disiplin seperti datang lebih awal diberikan apresiasi untuk dijadikan contoh untuk anak-anak yang lain. Jika terdapat anak yang melanggar seperti jail akan dicatat ke catatan jurnal. Jika sudah dilakukan beberapa kali maka harus ditindak dengan memberitahukan kepada orang tua, selain itu dilakukannya sidang kecil di ruang guru. Mereka menulis perjanjian untuk tidak melakukan pelanggaran itu lagi dengan tulisan mereka sendiri. Apabila anak datang telat untuk mengikuti upacara bendera mereka akan diberi nasihat dan dicatat pada catatan jurnal dan dijumlahkan berapa banyak mereka telat, jika melebihi batas maka guru akan bertanya kepada orang tuanya apa sebab anak didiknya terlambat.

\section{Pengembangan Diri Peserta Didik}

Para peserta didik yang berprestasi dilakukan pembinaan, dibina oleh guru yang kompeten. Bagi siswa yang mengikuti ekskul akan diikutsertakan lomba tetapi dilakukan seleksi terlebih dahulu, seperti: menganyam, menari, catur, karate, sains, dan lain-lain. Setelah diidentifikasi anakanak yang berprestasi dilakukanlah pembinaan secara khusus oleh guru-guru 
yang ditugaskan kepala sekolah. Mereka akan dicatat untuk seleksi ditingkat pengembangan diri. Pengembangan diri secara umum langsung di bawah penanganan kesiswaan yang lebih luas.

\section{Organisasi Peserta Didik}

Organisasi siswa terdiri dari pramuka, karate, bulu tangkis, bola voli, catur, tenis meja, band, angklung, paduan suara, futsal, sains, jurnalistik, dokter kecil, bahasa inggris, tari, dan komputer. Pramuka merupakan aktivitas wajib untuk siswa, selain itu siswa bebas memilih organisasi mana saja yang mereka minati.

\section{Kelulusan dan Alumni Peserta Didik}

Kelulusan dapat menjadi promosi sekolah untuk menarik minat masyarakat. SD Pertiwi kota Bogor selalu memiliki prestasi pada alumni, banyak lulusan yang melanjutkan pada Sekolah Menengah Pertama (SMP) favorit di Bogor.

\section{Peran Guru dalam Manajemen Peserta Didik}

Peran guru sangat penting, dari mulai perencanaan sampai kelulusan atau alumni. Di antara peran guru yaitu: (1) Pengelola, baik di dalam kelas atau di luar kelas. Guru memikirkan peserta didik dari awal hingga peserta didik lulus; (2) Puru selalu memberikan informasi mengenai segala sesuatu yang diperlukan peserta didik baik di dalam kelas, maupun di luar kelas; (3) Guru memberikan semangat kepada para peserta didik dengan membimbing dan pembinaan; (4) Memberikan kebutuhan para peserta didik; (5) Guru memberikan pembelajaran dan model yang baik bagi peserta didik; (6) Guru memberikan pembinaan untuk mengembangkan bakat dana minat peserta didik; (7) Guru memberikan bantuan untuk dapat mengevaluasi dan menilai peserta didik; (8) Guru memberikan bantuan untuk memperbaiki dan menilai proses pembelajarannya; (9) Dalam kegiatan belajar mengajar, guru selalu memberikan media yang menarik dalam pembelajaran; (10) Guru memberikan materi yang dibutuhkan peserta didik; (11) Memberikan kemudahan dan bantuan atas permasalahan peserta didik; dan (12) Memberikan penilaian baik dan buruk kepada peserta didik.

\section{Pembahasan}

\section{Perencanaan Peserta Didik}

Perencanaan peserta didik adalah aktivitas yang memikirkan aktivitas siswa dari mulai masuk sampai lulus sekolah. Langkahlangkah kegiatanya (procedure) terdiri dari: (1) Pembuatan skala prioritas, kontribusi kegiatan dalam pencapaian tujuan, priode waktu pelaksanaan, dan dukungan tenaga, biaya, dan peralatan; (2) Mengurutkan kegiatan, memberi penegasan kembali terhadap urutan agar menjadi jelas kegiatan menjadi prioritas; dan (3) Menyusun langkah-langkah kegiatan, agar segenap stakeholders pendidikan di SD memahami konsep yang harus dilakukan terlebih dahulu untuk individu dan tim. SD Pertiwi melakukan sensus sekolah guna mengetahui informasi para calon peserta didik di masyarakat. Sensus yang dilakukan dimulai dari masyarakat sekitar yang dekat dengan sekolah dan latar belakang masyarakat mengetahui usia umum calon peserta didik.

\section{Penerimaan Peserta Didik}

Kegiatan PPDB meliputi kebijakan penerimaan siswa, rekrutmen, kriteria penerimaan siswa, prosedur penerimaan 
siswa, dan permasalahan dalam penerimaan siswa (Imron, 2011). Hasil penelitian menyatakan bahwa proses penerimaan peserta didik pada SD Pertiwi Kota Bogor sesuai dengan konsep yang dikemukakan oleh Imron tesebut di atas.

\section{Orientasi Peserta Didik}

MOPD pada sekolah sesuai aturan yang menyatakan bahwa kegiatan tersebut memiliki visi memberikan pengetahuan dan pemahaman yang lebih detail tentang aktivitas yang ada di sekitar sekolah mulai dari program, struktur kepengurusan sekolah, aturan, tata tertib, proses pembelajaran, kegiatan kurikuler, ekstrakurikuler dan intrakurikuler sekolah, serta berbagai aktivitas sekolah dengan stakeholders agar siswa mengetahui, memahami, dan mampu merefleksikan nilai-nilai dan tujuan lembaga agar dapat membantu menjadikan sekolah memiliki budaya yang lebih baik dan kondusif sesuai dengan tujuan pendidikan nasional. Kegiatan MOPD pada SD Pertiwi sesuai dengan konsep (Vlamis, Bell, \& Gass, 2011) yang menyatakan bahwa one large study of adventure orientation programs found that students develop significantly greater degrees of social support compared to other pre-orientation experiences..... Other studies have determined further benefits, such as increases in GPA, higher retention, significant increases in friendship formation, and increased social skills development.

Kegiatan MOPD di sekolah memberikan semangat kepada peserta didik, menyalurkan bakat dan kemampuan peserta didik, meningkatkan kemampuan sosial peserta didik, melatih kemampuan psikologi dan fisik dengan cara berpetualang di luar ruangan.

\section{Pengelompokkan/Penempatan Peserta Didik}

Pengelompokan siswa dapat dilakukan dengan berbagai cara, diantaranya adalah melalui identifikasi hasil belajar siswa. Dalam melakukan penempatan siswa, biasanya guru membagi peserta didik lebih dari tiga kelompok, yakni: (1) Siswa yang memiliki kemampuan berfikir yang cepat; (2) Siswa dengan kemampuan berfikir sedang; dan (3) Siswa yang memiliki kemampuan berfikir yang lambat (Vlamis, Bell, \& Gass, 2011). Pengelompokan juga dapat dilakukan melalui perbedaan gender, latar belakang pengetahuan, kesukaan, usia, bidang keahlian, kebudayaan, dan tempat tinggal, atau di campuran setiap peserta didik dari kategori yang berbeda dari setiap kelas. Alison berpendapat bahwa overall, effective student participation in group work is an important learning outcome for higher education courses (Burke, 2011).

Pengelompokkan atau penempatan peserta didik pada SD Pertiwi tidak dipisahkan. Setiap satu kelas, terdapat peserta didik yang memiliki kemampuan berbeda-beda, terdapat laki-laki dan perempuan, latar belakang ekonomi, tempat tinggal, bahkan siswa yang memiliki kebutuhan khusus dapat berbaur dengan peserta didik lainnya. Penempatan kelas yang baik membantu guru dalam melakukan pengelolaan kelas yang dinamis dimana siswa akan di atur dan diberikan fasilitas kelas yang baik (Aliyyah \& Abdurakhman, 2016).

\section{Pencatatan Kehadiran dan Ketidakhadiran Peserta Didik}

Daftar hadir dapat dibuat dalam bentuk daftar hadir bulanan atau daftar hadir mingguan. Guru dengan memeriksa kehadiran menurut jam-jam pelajaran ini, 
dapat menghubungkan antara prestasi belajar dan kerajinan murid dalam mengikuti pelajaran yang bersangkutan. Dengan demikian dapat digunakan sebagai dasar pertimbangan untuk penentuan kebijaksanaan selanjutnya (Gunawan \& Djum Djum, 2017). Dasar alasan tidak hadirnya siswa antara lain: (1) bersumber dari keluarga; (2) bersumber dari diri sendiri; (3) bersumber dari sekolah; dan (4) bersumber dari lingkungan (Imron, 2011). Berdasarkan konsep tersebut, maka SD Pertiwi Kota Bogor telah menerapkan konsep para ahli dalam hal pencatatan kehadiran dan ketidakhadiran peserta didik.

\section{Evaluasi Peserta Didik}

Dua jenis pendekatan penilaian yang selalu digunakaan untuk menafsirkan skor menjadi nilai yaitu Penilian Acuan Norma (PAN). Tujuan penilaian ini lebih umum dan komprehensif serta meliputi berbagai bidang siswa dan tugas belajar yang benar. Penilaian ini bermaksud untuk mengetahui status peserta didik dalam berhubungan dengan skor kelompok peserta didik yang lain.

Penilaian Acuan Patokan (PAP), tujuan penilaian ini berfokus pada kolompok perilaku siswa yang khusus. Dengan kata lain penilaian ini digunakan untuk menyeleksi (secara pasti) status individu berkenaan dengan skor perilaku yang ditetapkan atau dirumuskan dengan baik (Imron, 2011). Teknik evaluasi adalah suatu cara yang ditempuh oleh seseorang dalam mengadakan evaluasi. Proses memperoleh data hasil belajar, pendidik agar menggunakan berbagai teknik penilaian secara komplementer sesuai dengan indikator kompetensi yang dinilai. Teknik evaluasi dapat diklasifikasikan menjadi dua, yaitu teknik tes dan teknik non- tes (Imron, 2011).

Teknik evaluasi tes, guru memberikan soal latihan setiap selesai tema pembelajaran. Sedikit demi sedikit, guru memberikan soal evaluasi jika pembelajaran telah selesai. Jika cara evaluasi tes tidak memungkinkan untuk mengetahui perkembangan peserta didik, guru menggunakan evaluasi non-tes. Evaluasi non-tes yang diberikan seperti tes lisan (tanya-jawab) dan perilaku. Contohnya teknik evaluasi peserta didik kelas 1 , tidak dapat dilakukan dengan teknik tes tertulis, maka guru menggunakan teknik tes lisan. Setiap minggu, para guru kelas SD Pertiwi selalu mengadakan penilaian harian untuk semua tema. Selain itu, juga mengadakan penilaian sikap setiap hari.

\section{Pelaporan Hasil Evaluasi Peserta Didik}

SD Pertiwi Kota Bogor melaporkan hasil evaluasi peserta didik dengan penuh tanggung jawab dan terbuka. Hal ini adalah suatu bentuk akuntabilitas terhadap orang tua murid menitipkan anaknya. Pelaporan hasil evaluasi dilakukan oleh guru kepada peserta didik sendiri, kepala sekolah, dan orangtua. Hal ini bertujuan agar ada timbal balik. Bagi kepala sekolah laporan tersebut untuk panduan atau data-data dalam mengambil keputusan, dan laporan yang diberikan kepada orangtua adalah untuk akuntabilitas atau laporan pertanggungjawaban atas kepercayaan menitipkan anaknya untuk mengikuti proses pembelajaran pada lembaga tersebut (Prihatin, 2011). 


\section{Sistem Tingkat dan Nontingkat Peserta Didik}

Beberapa pertimbangan kenaikan tingkat yaitu: 1) prestasi yang bersangkutan; 2) waktu kenaikan tinggat; dan 3) persyaratan administratif sekolah (Imron, 2011). Sistem non-tingkat dikembangkan berdasarkan pandangan psikologis yang mengatakan bahwa yang menyatakan bahwa walaupun keadaan siswa sama, namun pada kenyataanya tidak ada yang persis sama. Selalu ada perbedaan di antara peserta didik yang satu dengan yang lain. Untuk sistem non-tingkat, kelompok siswa yang memilih mata pelajaran yang sama akan dikelompokan dalam kelas yang memiliki guru yang sama, walaupun siswa tersebut berasal dari tahun ajaran yang berbeda. Dengan demikian, ada peserta didik yang dapat menyelesaikan program sangat cepat, sedang, lambat, dan bahkan ada yang sangat lambat (Imron, 2011). Sistem tingkat dan non tingkat peserta didik di SD Pertiwi sama halnya dengan kenaikan kelas. Secara umum, peserta didik di SD Pertiwi selalu bersama-sama naik dalam setiap angkatannya. Tidak ada peserta didik yang tertinggal maupun naik terlebih dahulu atau disebut juga akselerasi kenaikan kelas peserta didik.

\section{Mutasi dan Dropout Peserta Didik}

Terdapat mutasi peserta didik di SD Pertiwi kota Bogor. Hal ini karena terdapat beberapa alasan, yakni karena masalah orang tua yang dipindah tugaskan misalnya dari dalam kota ke luar kota atau sebaliknya, dan penyebab lain siswa mutasi karena pindah tempat tinggal, dan masalah rumah tangga. Kebijakan mutasi peserta didik dari luar ke dalam selalu melihat kondisi, jika jumlah peserta didik sudah banyak maka tidak diterima karena beberapa alasan, salah satunya adalah telah sesuai kuota. Adapun syarat mutasi adalah: (1) tidak konflik dengan sekolah; (2) mempunyai nilai yang baik dan naik kelas; (3) jika nilainya jelek, maka tetap bersekolah di tempat yang lama; dan (4) perpindahan siswa harus mendapat persetujuan tertulis dan institusi pengiriman. Dengan demikian, mutasi peserta didik akan diberikan jika memang memiliki alasan sesuai dengan ketentuan dibolehkannya mutasi di SD Pertiwi. Hal tersebut dilakukan dalam rangka tetap menjaga kualitas sekolah. Banyaknya siswa mutasi akan memberikan dampak negatif pada sekolah. Sehingga hal ini senantiasa diantisipasi oleh sekolah. Syarat institusi sebagai berikut: (1) daya tampung kelas yang ditetapkan memungkinkan; dan (2) tersediannya anggaran dalam institusi tersebut (Gunawan \& Djum Djum, 2017).

\section{Pelayanan Khusus Peserta Didik}

Layanan khusus menunjang siswa dalam menyelesaikan proses pembelajaran. Berbagai layanan tersebut sesuai konsep yang dikemukakan oleh Gunawan (2017) yang menyatakan bahwa layanan khusus tersebut misalnya layanan kafetaria, kesehatan, koperasi sekolah, perpustakaan, laboratorium, dan sebagainya. Apabila mengadopsi konsep layanan khusus, maka layanan hanya diberikan kepada siswa yang membutuhkan, artinya layanan ini bisa tidak memberikan kepada semua orang.

\section{Pembinaan Disiplin Peserta Didik}

SD Pertiwi kota Bogor melakukan pembinaan disiplin setiap hari. Ketika terdapat anak yang melanggar dicatat dan bagi anak yang sudah disiplin mengikuti peraturan sekolah akan diapresiasi. Bagi anak yang melanggar diingatkan untuk menerapkan disiplin. Setiap hari anak akan berbaris untuk catatan jurnal. Di kelas guru 
melakukan pembinaan disiplin dengan catatan jurnal, bagi anak-anak yang sangat disiplin seperti datang lebih awal diberikan apresiasi untuk dijadikan contoh untuk anak-anak yang lain. Jika terdapat anak yang melanggar seperti jail akan dicatat ke catatan jurnal. Jika sudah dilakukan beberapa kali maka harus ditindak dengan memberitahu kepada orang tua, selain itu dilakukaknnya sidang kecil di ruang guru. Mereka menulis perjanjian untuk tidak mengulangi kesalahan itu lagi dengan tulisan mereka sendiri. Jika ada anak yang telat untuk mengikuti upacara bendera mereka akan diberi nasihat dan dicatat pada catatan jurnal dan dijumlahkan berapa banyak mereka telat, jika melebihi batas maka guru akan bertanya kepada orang tuanya apa sebab anak didiknya terlambat. Pembinaan kesiswa yang baik merupakan pengaruh dari disiplin kerja yang baik pada SD Pertiwi Kota Bogor (Aliyyah, Lutfah, \& Lathifah, Pengelolaan Tenaga Pendidik pada Sekolah Dasar, 2017).

Pembinaan disiplin searah dengan yang dikemukakan oleh Olaitan, Mohammed, \& Ajibola (2013) yang menyatakan bahwa: Discipline defines the limitations of an individual or a group of people. It is the practice of restraint, which may be selfimposed. The study of psychology reveals that a person possesses boundless urges and impulses, which are constantly seeking expression. These include need for security, sexual activities, exploration and success. On the other hand, the society stipulates laws and traditions, which does not permit free expression of these inner forces without following the appropriate procedure acceptable by balance.

\section{Organisasi Peserta Didik}

SD Pertiwi melaksanakan kegiatan kesiswaan terwujud seperti organisasi sekolah. Kegiatan organisasi yang diikuti siswa sepadan dengan pendapat Yadav (2016) dan Olaitan, Mohammed, \& Ajibola (2013) dengan pernyataan empat jalur pembinaan kesiswaan adalah: (1) organisasi kesiswaan; (2) latihan kepemimpinan; (3) kegiatan ekstrakulikuler; dan (4) kegiatan wawasan wiyata mandala. Hal ini sesuai dengan pernyataan bahwa extracurricular activities focus on institutional goals, such as building and sustaining community on campus as well as student retention (Neetu Singh Yadav, 2016).

\section{Peran Guru dalam Manajemen Peserta Didik di SD Pertiwi Bogor}

Guru pada SD Pertiwi Kota Bogor mencerminkan pengajar yang juga memiliki jiwa inspiratory dan informator. Hal tersebut sesuai dengan konsep yang dijelaskan oleh Harden \& Crosby (2000) yang menyatakan bahwa the six areas of activity of the teacher can be summarised as: (1) The teacher as information provider; (2) The teacher as role model; (3) The teacher as facilitator; (4) The teacher as assessor; (5) The teacher as planner; and (6) The teacher as resource developer. Guru adalah sosok yang memiliki kemampuan dan seni dalam mengelola kemampuan siswa menjadi manusia yang berdaya guna. Kemampuan guru tersebut merupakan pondasi awal dalam merefleksikan kewajiban, tugas dan tanggung jawabnya sebagai pembimbing dalam mengembangkan minat, bakat dan potensi siswa menjadi sosok diri yang kuat dan mampu berdaya saing dalam menghadapi tantangan zaman di era globalisasi. Melalui rekrutmen, seleksi, pembinaan, layanan, dan manajemen 
alumni yang baik pada satuan SD, akan membuat siswa mampu mengembangkan dirinya menjadi manusia paripurna secara cepat dan menyeluruh. Dengan demikian, baik elemen siswa maupun guru menjadi bagian penting dalam proses pengembangan sumber daya manusia pendidikan di Indonesia.

\section{KESIMPULAN DAN IMPLIKASI}

\section{Kesimpulan}

Manajemen kesiswaan pada SD Pertiwi dilakukan mulai dari: (1) perencanaan; (2) penerimaan peserta didik; (3) masa orientasi peserta didik (MOPD); (4) pengelompokkan/penempatan peserta didik; (5) presensi siswa; (6) evalusi peserta didik; (7) pelaporan hasil evaluasi; (8) sistem tingkat dan non-tingkat; (9) mutasi dan dropout peserta didik; (10) layanan khusus kepada peserta didik; (11) pembinaan disiplin; (12) pengembangan diri; (13) organisasi siswa; (14) alumni. Kegiatan kesiswaan pada SD Pertiwi terlaksana secara objektif dan sistematis. Selanjutnya, peran guru dalam manajemen kesiswaan urgent dilakukan untuk mengatur siswa selama di kelas. Guru memiliki tanggung jawab dan peran dalam memberikan kontribusi untuk membantu mengembangkan potensi siswa dari berbagai unsur.

\section{Implikasi}

Manajemen kesiswaan memberikan solusi dan alternatif handal dalam mengelola siswa, karena memberikan pengaturan siswa mulai dari diterima sekolah sampai pada siswa tersebut menjadi alumni. Oleh sebab itu, sebaiknya pihak sekolah mampu memberikan rencana manajemen yang sistematis untuk peserta didik yang unggul guna memberikan pelayanan terbaik bagi siswa.

\section{DAFTAR PUSTAKA}

Aliyyah, R. R., \& Abdurakhman, O. (2016). Pengelolaan Kelas Rendah di SD Amaliah Ciawi Bogor. Jurnal Sosial Humaniora, 7(2), 81-95.

Aliyyah, R. R., Lutfah, S. A., \& Lathifah, Z. K. (2017). Pengelolaan Tenaga Pendidik pada Sekolah Dasar. Didaktika Tauhidi: Jurnal Pendidikan Guru Sekolah Dasar, 4(2), 75-86.

Burke, A. (2011). Group Work: How to Use Groups Effectively. The Journal of Teaching, 11(2).

Djamarah, S. B. (2010). Guru dan Anak Didik dalam Interaksi Edukatif. Jakarta: Rineka Cipta.

Gunawan, I., \& Djum Djum, N. B. (2017). Manajemen Pendidikan. Malang: Alfabeta.

Harden, R. M., \& Crosby, J. (2000). The Good Teacher is More Than A Lecture - the Twelve Toles of The Teacher. Scotland: University of Dundee.

Imron. (2011). Manajemen Peserta Didik Berbasis Sekolah. Jakarta: PT Bumi Aksara.

Imron, A., \& Burhanudin. (2003). Manajemen Peserta Didik. Malang: Universitas Negeri Malang.

Kristiawan, M. (2017). Manajemen Pendidikan. Yogyakarta: Deepublish.

Kudianta. (2016). Pengelolaan Peserta Didik Baru. Jakarta: Kementerian Pendidikan dan Kebudayaan.

Olaitan, T., Mohammed, A. N., \& Ajibola, A. L. (2013). Management of Disciplinary Problems in Secondary Schools: Jalingo Metropolis in Focus. Global Journal of Human Social Science Linguistics \& Education, 13(14). 
Prihatin, E. (2011). Manajemen Peserta Didik. Bandung: Alfabeta.

Sugiyono. (2017). Metode Penelitian Pendidikan. Bandung: Alfabeta.

Vlamis, E., Bell, J. B., \& Gass, M. (2011). Effects of a College Adventure Orientation Program on Student Development Behaviors. Journal of Experiential Education, 34(2).
Yadav, N. S. (2016). Impact of Extracurricular Activities on Students by Professional Institutions. Journal of Business and Management, 18(1).

Yusuf, A. M. (2015). Penelitian Kuantitatif, Kualitatif, dan Penelitian Gabungan. Jakarta: Prenadamedia Group. 